\title{
Student- Centered Approach to Teaching and Learning in Higher Education for Quality Enhancement
}

\author{
Dr. Subhaarati Oinam \\ (Department of Education, N. G. College, Manipur, India) \\ You cannot teach a man anything. You can only help him discover it within himself. \\ Galileo Galilei
}

\begin{abstract}
Quality education in Higher Education is needed today, so that people living in the society and nation as a whole, acquire the necessary skills and competencies which is required for living meaningfully in a competitive, global world. High quality education is education that meets the needs of the student and helps in promoting their future development. A teacher's role becomes very important for enhancing quality education. An effective teacher understands that teaching involves wearing multiple hats to ensure that the school day runs smoothly and all students receive a quality education. To bring about quality education, a shift of focus of activity from the teacher to the learners or often termed as Student-centered approach to teaching and learning is necessary. Student-centered approach includes active learning, cooperative learning, and inductive teaching and learning. This paper attempts to find out the importance of student - centered approach to learning in bringing about quality education in Higher Education.
\end{abstract}

Key words: quality, student-centered learning.

\section{INTRODUCTION}

Higher education is the backbone of any society. Higher education includes college and university teaching- learning towards which students' progress to attain higher educational qualification. It is where indepth knowledge and understanding is imparted to the students so as to advance to new frontiers of knowledge in different walks of life. It is about knowing more and more about less and less. Very importantly, it develops the student's ability to question and seek truth and makes him/her competent to critique on contemporary issues thereby broadening the intellectual powers of the individual within a narrow specialization, and also gives him/her a wider perspective of the world around (NAAC, 2006).

According to Ronald Barnett (1992), there are four predominant concepts of higher education:i) Higher education as the production of qualified human resources: In this view, higher education is seen as a process in which the students are counted as "products" absorbed in the labour market. Thus, higher education becomes input to the growth and development of business and industry.

ii) Higher education as training for a research career: Here, higher education is preparation for qualified scientists and researchers who would continuously develop the frontiers of knowledge. Quality within this viewpoint is more about research publications and transmission of the academic rigour to do quality research.

iii) Higher education as the efficient management of teaching provision: Many strongly believe that teaching is the core of educational institutions. Thus, higher education institutions focus on efficient management of teaching-learning provisions by improving the quality of teaching, enabling a higher completion rate among the students.

iv) Higher education as a matter of extending life chances: In this view, higher education is seen as an opportunity to participate in the development process of the individual through a flexible, continuing education mode. All these four concepts of higher education are not exclusive; rather they are integrated and give an overall picture of what higher is in higher education. In short, teaching, research and extension form the three main functions of higher education (NAAC, 2006).

India's higher education system is the third largest in the world, next to the United States and China and has expanded at a fast pace by adding nearly 20,000 colleges and more than 8 million students in a decade from 2000-01 to 2010-11. As of 2016, India has 799 universities, with a break up of 44 central universities, 540 state universities, 122 deemed universities, 90 private universities, 5 institutions established and functioning under the State Act, and 75 Institutes of National Importance which include AIIMS, IIT's and NIT's among others (Wikipedia, 2017). Looking at the present scenario of Higher Education in India, it has been found that only $10 \%$ of Indian youth go to college while it is 40-50\% in developed countries (Nagoba, and Mantri, 2015). 


\section{ROLE OF HIGHER EDUCATION IN THE SOCIETY}

Higher education is generally understood to cover teaching, research and extension. Higher education is the source or feeder system in all walks of life and therefore supplies the much-needed human resources in management, planning, design, teaching and research. Scientific and technological advancement and economic growth of a country are as dependent on the higher education system as they are on the working class. Higher education also provides opportunities for life- long learning, allowing people to upgrade their knowledge and skills from time to time based on the societal needs (NAAC, 2006).

The report of the UNESCO International Commission on Education in the $21^{\text {st }}$ Century titled "Learning: The Treasure Within" (popularly known as Delors Commission) emphasized four pillars of education: learning to know, learning to do, learning to live together and learning to be. While, higher education intends to inculcate all these four in individuals and the society, the report highlighted the following specific functions of higher education too:

- To prepare students for research and teaching;

- To provide highly specialized training courses adapted to the needs of economic and social life;

- To be open to all, so as to cater to the many aspects of lifelong education in the widest sense; and

- To promote international cooperation through internationalization of research, technology, networking, and free movement of persons and scientific ideas (UNESCO, 1996).

\section{OBJECTIVES OF THE STUDY}

1) To provide ideas of student-centered education.

2) To raise awareness of the advantages and disadvantages of teacher-centered education and student-centered education.

\section{QUALITY EDUCATION}

'Quality' is a much-debated term. The word quality comes from the Latin word qualis meaning 'what kind of'. In the words of Pirsig (1974), Quality ... you know what it is, yet you don't know what it is. But that's self-contradictory. But some things are better than others, that is, they have more quality. But when you try to say what the quality is, apart from the things that have it, it all goes poof? There's nothing to talk about it. But if you can't say what Quality is, how do you know what it is, or how do you know that it even exists? If no one knows what it is, then for all practical purposes, it doesn't exist at all. But for all practical purposes it really does exist... So round and round you go spinning mental wheels, and nowhere finding any place to get traction. What the hell is Quality? What it is? (p. 179). This implies that quality means different things to different people (NAAC, 2006).

In his book 'The World Crises in Education: The View from the Eighties', Coombs (1985) described quality as, "..qualitative dimensions means much more than the quality of education as customarily defined and judged by student learning achievements, in terms of traditional curriculum and standards. Quality (.....) also pertains to the relevance of what is taught and learned - to how well it fits the present and future needs of the particular learners in question, given their particular circumstances and prospects. It also refers to significant changes in the educational system itself, in the nature of its inputs (students, teachers, facilities, equipment, and supplies); its objectives, curriculum and educational technologies; and its socioeconomic, cultural and political environment." (Coombs, 1985, p. 105).

Quality education as given by UNICEF includes:

$\square$ Learners who are healthy, well-nourished and ready to participate and learn, and supported in learning by their families and communities;

$\square$ Environments that are healthy, safe, protective and gender-sensitive, and provide adequate resources and facilities;

$\square$ Content that is reflected in relevant curricula and materials for the acquisition of basic skills, especially in the areas of literacy, numeracy and skills for life, and knowledge in such areas as gender, health, nutrition, HIV/AIDS prevention and peace.

$\square$ Processes through which trained teachers use child-centred teaching approaches in well-managed classrooms and schools and skilful assessment to facilitate learning and reduce disparities.

$\square$ Outcomes that encompass knowledge, skills and attitudes, and are linked to national goals for education and positive participation in society (UNICEF, 2000). 


\section{PARADIGM SHIFT FROM TEACHER-CENTERED LEARNING TO STUDENT- CENTERED LEARNING}

Higher Education plays an important role in contributing to economic development, social progress and political democracy in independent India. Higher education also helps increase wages and productivity that directly enrich individuals and society (Singh, n. a.). It is the quality of higher education that decides the quality of human resources in a country. Over the years, there has been a tremendous expansion of educational opportunities at all levels, particularly in higher education, and various committees and commissions on education have emphasized directly or indirectly the need for improvement and recognition of quality in Indian higher education system (NAAC, 2006). As per the available reports, two third of the Indian universities are providing sub-standard education while $90 \%$ colleges in India are below average. Nowadays, students / teachers are running after attaining or providing degrees and there is no concern for gaining knowledge and wisdom thereby making most of the institutions a factory of degrees only. Attendance has dropped drastically in most of the institutions and class room teaching has become only a ritual, which is followed mechanically. In short, the overall scenario of higher education in India does not match with the global quality standards (Nagoba, and Mantri, 2015). Students are concern only for getting high marks and they study only for grabbing jobs. There is absence of creativity in them, they are hard-worker but not innovative. There is a great need to bring about a change in higher education (Singh, J. D.). There is a need to bring about quality education in higher education. For this, adoption of student-centered learning in classroom teaching by the teachers can be one of the means to bring quality in higher education.

From various pedagogical research, it has been found that what teachers do in the classroom is undoubtedly the key educational determinant in student learning and achievement. To achieve the desired learning outcomes of the students in the most effective way, it is therefore important to identify and promote the most effective practices. From this perspective, there is a general rejection (on the part of researchers, decisionmakers, teacher trainers, educational support staff, parents, classroom practitioners) of what is referred to as "traditional" teaching. This is a form of teaching, dominated by the teacher, which relegates pupils to a passive role, reduces their classroom activity to the memorization of data to be recited to the teacher, and in particular, leads to the acquisition of skills of a lower taxonomic level (Gauthier and Dembele, 2004). To bring about quality education, the learning outcome of the students is also important. It is here, student- centered learning comes in. Swami Vivekananda laid emphasis on self- teaching or self- learning. According to him, the child is regarded as the pivotal point of education and education must be based on the needs of the child. He is the storehouse of knowledge and this knowledge resides within the child. Until the inner teacher opens, all outside teaching is vain (Purkait, 1995).

In the Education International project-Time for a New Paradigm in Education: Student Centered Learning, the definition of Student-Centred Learning (SCL) is given as- Student-Centred Learning represents both a mindset and a culture within a given higher education institution and is a learning approach which is broadly related to, and supported by, constructivist theories of learning. It is characterized by innovative methods of teaching which aim to promote learning in communication with teachers and other learners and which take students seriously as active participants in their own learning, fostering transferable skills such as problem-solving, critical thinking and reflective thinking.

Student-Centred Learning comprised of the following elements (Education International, 2010):

- The reliance on active rather than passive learning;

- An emphasis on deep learning and understanding;

- Increased responsibility and accountability on the part of the student;

- An increased sense of autonomy in the learner;

- An interdependence between teacher and learner;

- Mutual respect within the learner-teacher relationship; and

- A reflexive approach to the teaching and learning process on the part of both the teacher and the learner.

In the traditional approach to college teaching, most class time is spent with the professor lecturing and the students watching and listening. The students work individually on assignments, and cooperation is discouraged (Felder, n. a.). When students work alone, they don't learn to collaborate with other students, and communication skills may suffer. Teacher-centered instruction can get boring for students and their minds may wander, and even may miss important facts. In teacher-centered instruction, students are not allowed to express themselves, ask questions and direct their own learning (Concordia University, 2016).

In student-centered instruction, students and instructors share the focus. Instead of listening to the teacher exclusively, students and teachers interact equally. Group work is encouraged, and students learn to collaborate and communicate with one another (Concordia University, 2016). This approach include active learning, in which students solve problems, answer questions, formulate questions of their own, discuss, explain, debate, or brainstorm during class; cooperative learning, and inductive teaching and learning (Felder, n. a.). Some disadvantages of this approach are -as students are talking and interacting, classrooms are often busy, 
noisy and chaotic. It can be difficult on the part of the teachers to manage all students' activities at once when students are working on different stages of the same project. Because the teacher doesn't deliver instruction to all students at once, some students may miss important facts. Some students prefer to work alone, so group work can become problematic (Concordia University, 2016).

In recent years, more teachers have moved toward a student-centered approach. However, some students maintain that teacher-centered education is the more effective strategy. In most cases, it is best for teachers to use a combination of approaches to ensure that all student needs are met. When both approaches are used together, students can enjoy the positives of both types of education. Instead of getting bored with teachercentered education or losing sight of their goals in a completely student-centered classroom, pupils can benefit from a well-balanced educational atmosphere (Concordia University, 2016)

\section{BENEFITS OF SCL}

The benefits of SCL includes providing skills for life of the students, creating independent learners and responding to the changing and differing needs of individual students. SCL helps in quality enhancement in higher education. Overall, this approach provides benefit to the institutions, teachers, society and students (Education International, 2010).

\section{CONCLUSION}

Quality education is a prerequisite for national, regional and global development. For delivery of quality education, quality teachers who are committed to teaching and equipped with necessary knowledge, skills and competencies for effective teaching is needed. Teachers must give a thought of adopting studentcentered approach of teaching so as to bring about quality education in higher education.

\section{REFERENCES}

[1] Basavraj S., Nagoba, Sarita B., and Mantri (2015). Role of Teachers in Quality Enhancement in Higher Education. Journal of Krishna Institute of Medical Sciences University, Vol. 4, No. 1, Jan-Mar. pp-177182. Retrieved from http://jkimsu.com/jkimsuvol4no1/JKIMSU,\%20Vol.\%204,\%20No.\%201,\%20JanMar\%202015\%20Page\%20177-182.pdf, accessed on 3/3/17 at 8:24 a.m.

[2] [Concordia University. (2010). Which is Best: Teacher-Centered or Student-Centered Education? Retrieved from http://education.cu-portland.edu/blog/classroom-resources/which-is-best-teachercentered-or-student-centered-education/, accessed on 8/3/17 at 12:40 p.m.

[3] Coombs, P. H. (1985) The World Crises in Education: The View from the Eighties. Oxford:Oxford University Press.

[4] Education International. (2010). Student-Centred Learning. Retrieved from http://pascl.eu/wpcontent/uploads/SCL_toolkit_ESU_EI.pdf, accessed on 4/3/17 at 1:17p.m.

[5] Felder, R. (N.A). Student-centered teaching and learning Retrieved from http://www4.ncsu.edu/unity/lockers/users/f/felder/public/Student-Centered.html, accessed on 4/3/17 at $1: 29$ p.m.

[6] Gauthier, C., and Dembele, M. (2004). Quality of teaching and quality of education: a review of research findings. "Paper commissioned for the EFA Global Monitoring Report 2005, The

Quality Imperative". Retrieved from http://unesdoc.unesco.org/images/0014/001466/146641e.pdf, accessed on 4/3/17 at 6:52 a.m.

[7] Mishra, S. (2006). Quality Assurance in Higher Education. NAAC, Bangalore.Retrieved from http://www.naac.gov.in/docs/Quality\%20Assurance\%20in\%20Higher\%20Education\%20An\%20Introduc tion.pdf, accessed on 13/3/17 at 4:05 p.m.

[8] Purkait, B. W. (1998). Great Educators and their Philosophics. Calcutta, New Central Book Agency.

[9] [Singh, J. D. ( n. a.). Higher Education in India - Issues, Challenges and Suggestions. Retrieved from http://www.gvctesangaria.org/websiteimg/publications/jdarticle.pdf, accessed on 4/3/17 at 3:12 p.m.

[10] UNESCO (1996). Learning: The Treasure Within, (Report of the International Commission on Education to UNESCO for the Twenty First Century), Paris: UNESCO (Chair: Jacques Delors).

[11] UNICEF. (2000). Defining Quality in Education. Retrieved from https://www.unicef.org/education/files/QualityEducation.PDF, accessed on 3/3/17 at 12:27 p.m.

[12] Wikipedia (2017). Retrieved from https://en.wikipedia.org/wiki/Higher_education_in_India, accessed on $15 / 3 / 17$ at $8: 43$ a.m. 